ZOOLOGIA 27 (2): 184-190, April, 2010

doi: $10.1590 /$ S1984-46702010000200005

\title{
Food habits of Anilius scytale (Serpentes: Aniliidae) in the Brazilian Amazonia
}

\author{
Gleomar F. Maschio; Ana Lúcia da C. Prudente; Francílio da S. Rodrigues \& Marinus S. Hoogmoed
}

Laboratório de Herpetologia, Museu Paraense Emílio Goeldi. Avenida Perimetral 1901, Terra Firme, 66077-530 Belém, Pará, Brazil.

Corresponding Author. E-mail: gleomarmaschio@yahoo.com.br

\begin{abstract}
Information on the diet of Anilius scytale is provided based on the analysis of 162 specimens from the Brazilian Amazonia. Amphisbaenians (Aulura anomala Barbour, 1914; Leposternon polystegumn [Duméril, 1951] and Amphisbaena sp.), which are highly specialized for a fossorial life, accounted for $81.25 \%$ of the recorded items, followed by snakes - Anilius scytale (Linnaeus, 1758), and Tantilla melanocephala (Linnaeus, 1758): 12.5\% - and caecilians Caecilia cf. gracilis Shaw, 1802: 6.25\%. We found a positive, although not significant, relationship between the snoutvent length of $A$. scytale and the total length of the prey and a tendency for smaller specimens to ingest proportionately larger prey. Anilius scytale forages mainly on the ground, at night, as well as in aquatic environments. The non-selective capture of either proportionately large or small prey by $A$. scytale may reflect the opportunistic nature of the encounters. A tendency of the juveniles of this species to ingest proportionately larger prey may be associated with either a low availability of prey with a size compatible to that of the juveniles, or with their inexperience in selecting prey. Ingestion of prey headfirst may be an attempt to minimize the risk of injury the prey could cause through their rigid, pointed and sharp structures or powerful bites.
\end{abstract}

KEY WORDS. Basal snakes; diet.

Studies on the natural history of snakes concentrate largely on Colubroidea and on Boidae, Pythonidae, Elapidae and Viperidae (Harlow \& Shine 1992, Slip \& Shine 1988, Bertona \& Chiaraviglio 2003, Lourdais et al. 2006). Basal snakes, which include Anilius Oken, 1816, Cylindrophis Wagler, 1828, and Anomochilus Berg, 1901, as well as the monophyletic Uropeltidae, show in general narrow distributions and their biology is still very poorly known (Maschio et al. 2007).

Anilius scytale (Linnaeus 1758), Aniliidae (Fig. 1) is commonly found in the Amazonian forest (Dixon \& Sorni 1977, Duellmann 1978, Cunha \& Nascimento 1981, 1993, Martins \& OLIVEIRA 1998), although it has also been recorded in deforested areas, in areas of Cerrado (states of Goiás and Mato Grosso, Brazil), and in humid forest enclaves within the Caatinga region (state of Ceará, Brazil) (SILVA-JR 2001). The scarce information available indicates that $A$. scytale has fossorial habits and can occasionally be seen both on the ground and in aquatic environments, where it forages mainly at night. It can also be active during the day, but this habit has been observed less frequently (e.g. Beebe 1946, Cunha \& Nascimento 1978, Duellman 1978, Dixon \& Soini 1986, Vanzolini 1986, Martins \& Oliveira 1998). Recently, MASCHIO et al. (2007) observed that females of A. scytale in Eastern Amazonia have seasonal reproduction, with developed follicles recorded mainly from the end of the dry season (May to October) to the middle of the rainy season (November to April). Newborns were recorded mainly in the rainy season.

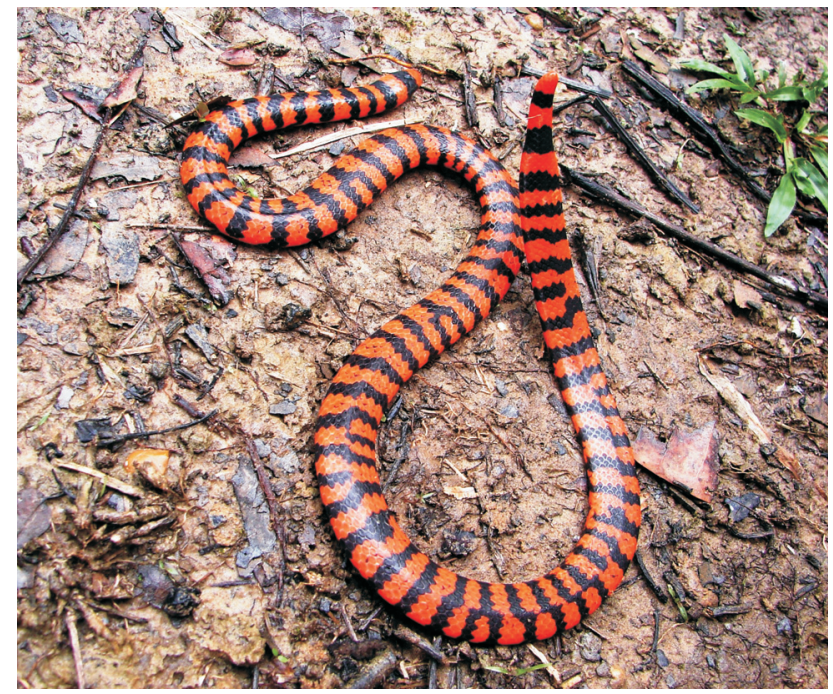

Figure 1. Dorsal view of $A$. scytale from Coari, state of Amazonas, Brazil, showing defense posture. Photo: G.F. Maschio.

Nevertheless, knowledge about the diet of this species is based on anecdotal information, which records as food items amphisbaenians, small snakes and, occasionally, fish such as Synbranchus marmoratus Bloch, 1795 (BeEBe 1946, Cunha \& 
Nascimento 1978, 1981, Greene 1983, Martins \& Oliveira 1998, MAschIO et al. 2005). Information on the feeding behavior of the species is virtually non-existent. MARques \& SAZIMA (2008) observed, under artificial conditions, predatory sequences of two individuals of $A$. scytale, which were similar to constriction behavior. These authors recommended that further studies be undertaken to obtain more conclusive data about this behavior in $A$. scytale.

The diet of a species is one of the most important aspects of its ecology and detailed information about dietary habits are, in most cases, necessary for understanding environmental and/or behavioral issues (Clark 2002). Moreover, these aspects can underpin our understanding of trophic relationships in different ecological communities (RoDRíGuEz-Robles 2002). Thus, the present study provides information on the dietary habits of $A$. scytale in Brazilian Amazonia, namely: 1) the composition of its diet; 2) the variation in the absolute frequency of items in the dry season and months with higher rates of annual precipitation in the Amazonia; 3 ) the relationship between size of predator and that of prey; and 4) the level of behavioral specialization with respect to the environment and the ingestion prey.

\section{MATERIAL AND METHODS}

We analyzed 162 specimens (79 males and 83 females) from the Brazilian Amazonia, deposited in the Herpetology Collection of the Museu Paraense Emílio Goeldi (MPEG) between 1971 and 2007 (Appendix 1). Females and males with SVL greater than 515 and $430 \mathrm{~mm}$, respectively, were considered as sexually mature (MASCHIO et al. 2007).

The stomachs and intestines of all specimens were analyzed by making a longitudinal ventral incision to verify the presence or absence of contents. The direction of ingestion (antero-posterior or postero-anterior) was determined by observing the position of the prey's head in relation to that of the predator. All items were removed, identified to the lowest possible taxonomic level, weighed, measured, and deposited in the MPEG collection (Appendix 2).

We measured the snout-vent length (SVL), total mass and largest diameter of all specimens of $A$. scytale $(\mathrm{TLPr}=$ total length of predator, $\mathrm{MPr}=$ mass of predator, $\mathrm{DPr}=$ diameter of predator) as well as that of the food items (TLPy = total length of prey, MPy = mass of prey, DPy = diameter of prey) where possible. Partially digested items were identified and compared with a sample of complete specimens of the same species from the MPEG collection, from which we took the same measurements.

To test the normality of the analyzed data, we used the D'Agostino test (D'Agostino et al. 1990). We then applied Spearman's linear correlation (ZAR 1996) to verify the correlation between the SVL of $A$. scytale and the TLPy and the correlation between the SVL of $A$. scytale with the proportion TLPy versus SVL. The software used was Statistica 6.0. (STATSOFT 2001).

\section{RESULTS}

Of the 162 specimens analyzed, only 21 (12.9\%) had some type of food item in the digestive tract. Of these, we were able to identify the content up to the genus level of 16 (76\%; 12 females and 4 males) specimens and we found only scales in the digestive tract of the other five. Of the 16 identified prey specimens, 13 (81.2\%) were amphisbaenians, two (12.5\%) were snakes and one $(6.2 \%)$ was a caecilian. Among the amphisbaenians, specimens of Amphisbaena Linnaeus, 1758 were the most consumed items ( $\mathrm{n}=7,43.75 \%$ of all items recorded: Amphisbaena amazonica Vanzolini, 1951 [ $\mathrm{n}=2]$, A. mitchelli Procter, 1923 $[\mathrm{n}=1]$, and four undetermined specimens), followed by specimens of Aulura anomala Barbour, 1914 and Leposternon polystegum (Duméril, 1851) ( $\mathrm{n}=3$ for both; $18.8 \%$ of the recorded items) (Tab. I). The two snakes, A. scytale $(\mathrm{n}=1)$ and Tantilla melanocephala (Linnaeus, 1758) $(\mathrm{n}=1)$, and the caecilian, Caecilia cf. gracilis Shaw, $1802(\mathrm{n}=1)$, each accounted for $6.3 \%$ of the total items recorded (Tab. I).

The direction of ingestion of all the food items that were in adequate conditions for analysis (intact or only partially digested) was antero-posterior.

Of the specimens containing food items, $81 \%$ were collected in the dry season (May to October), while 19\% were collected in months with higher rates of annual precipitation (November to April) (Fig. 2).

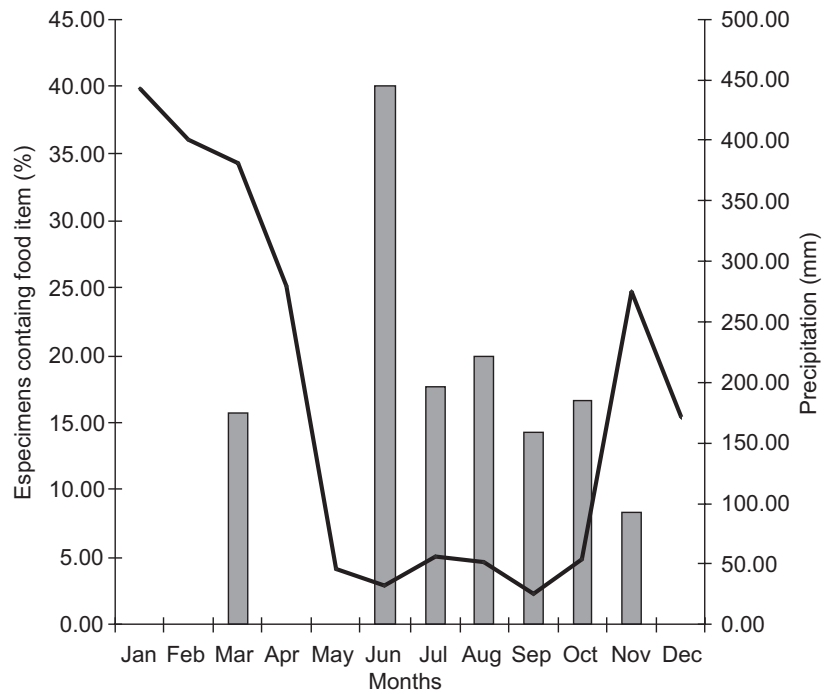

Figure 2. Relation between the numbers of food items registered in the stomachs of Anilius scytale, in percentage for the months of the year, in Brazilian Amazonia.

There was no correlation between the SVL of $A$. scytale and the total length of the prey ( $\mathrm{rs}=0.08, \mathrm{t}=0.2654, \mathrm{p}=0.8$ ) (Fig. 3). But a tendency for smaller specimens to ingest propor- 

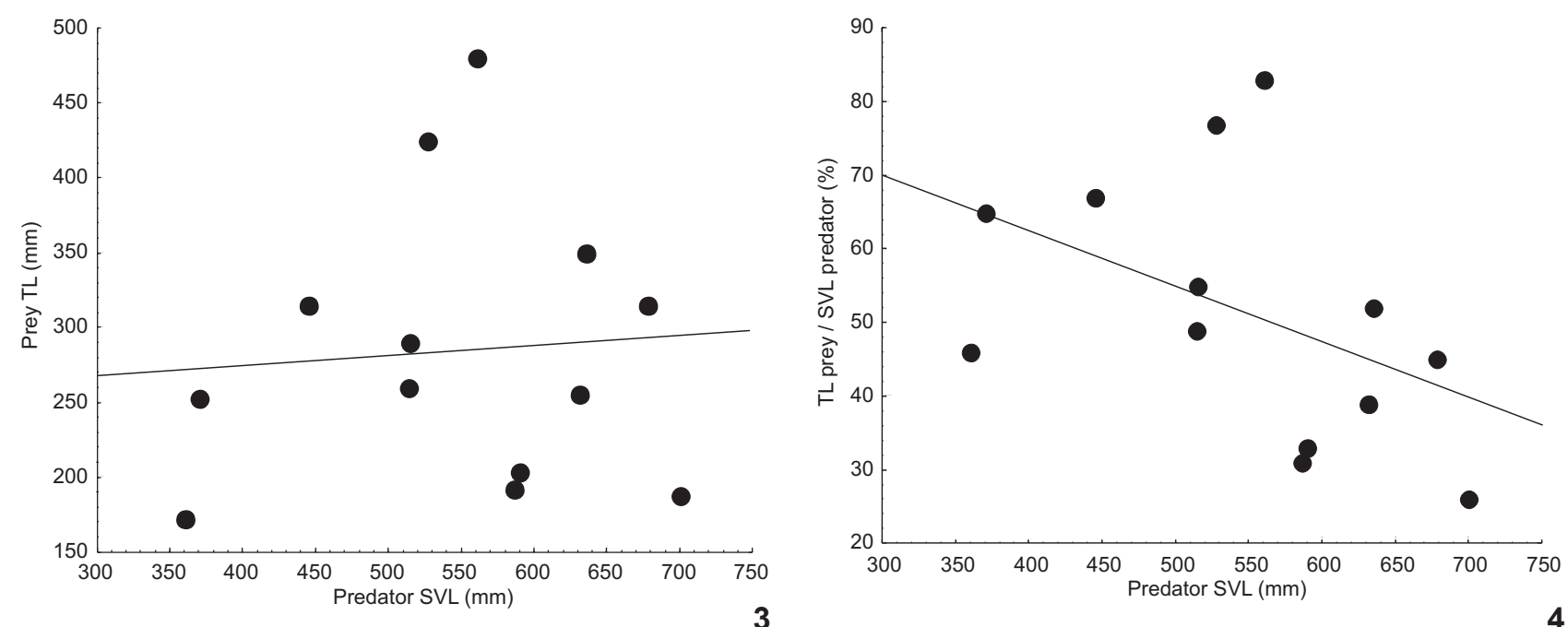

Figures 3-4. Relation between snout-vent-length of $A$. scytale and the: (3) total length of its items; (4) proportion of the total length of the prey in relation to the snout-vent length of $A$. scytale in Brazilian Amazonia.

Table I. Preys and their frequency in the diet of 16 specimens of $A$. scytale, in Brazilian Amazon. (SVLPr) snout-vent length of predator $(\mathrm{mm}),(\mathrm{DPr})$ diameter predator (millimeters), (\%) the percentage which each group of prey items represents of the total number of food items analyzed, (MPy) weight of prey (g), (TLPy) total length of prey in millimeters, (DPy) diameter of prey (mm), (DPy/Pr) proportional diameter of prey in relation to diameter of predator, (SVLPy/Pr) proportion total length of prey in relation to snout-vent length of predator.

\begin{tabular}{|c|c|c|c|c|c|c|c|c|c|}
\hline Sex Predator & SVLPr & DPr & Prey & $\%$ & MPy & TLPy & DPy & $\mathrm{DPy} / \mathrm{Pr}$ & SVL Py/Pr \\
\hline & & & nphibia & & & & & & \\
\hline & & & Caeciliidae & & & & & & \\
\hline \multirow[t]{3}{*}{ Female } & 635 & 18.04 & Caecilia cf. gracilis & 6.25 & 8.5 & 350 & 7.06 & 0.39 & 0.55 \\
\hline & & & uamata & & & & & & \\
\hline & & & Amphisbaenidae & 81.30 & & & & & \\
\hline Female & 560 & 14.32 & Leposternon polystegum & & 35.0 & 480 & 12.03 & 0.84 & 0.86 \\
\hline Female & 527 & 13.87 & Leposternon polystegum & & 37.0 & 425 & 11.16 & 0.80 & 0.81 \\
\hline Female & 678 & 14.89 & Leposternon polystegum & & 19.0 & 315 & 10.22 & 0.69 & 0.46 \\
\hline Female & 515 & 14.68 & Aulura anomala & & 13.0 & 290 & 9.81 & 0.67 & 0.56 \\
\hline Female & 514 & 12.24 & Aulura anomala & & 14.0 & 260 & 10.03 & 0.82 & 0.51 \\
\hline Female & 590 & 13.51 & Aulura anomala & & 7.5 & 205 & 7.61 & 0.56 & 0.35 \\
\hline Female & 586 & 12.86 & Amphisbaena fuliginosa & & 6.4 & 192 & 8.06 & 0.63 & 0.33 \\
\hline Male & 700 & 19.21 & Amphisbaena fuliginosa & & 6.0 & 188 & 7.01 & 0.36 & 0.27 \\
\hline Female & 360 & 8.84 & Amphisbaena mitchelli & & 2.5 & 172 & 4.59 & 0.52 & 0.48 \\
\hline Female & 631 & 14.40 & Amphisbaena sp. (und.) & & 14.0 & 255 & 9.13 & 0.63 & 0.40 \\
\hline Female & 610 & - & Amphisbaena sp. (und.) & & - & - & - & - & - \\
\hline Male & 535 & - & Amphisbaena sp. (und.) & & - & - & - & - & - \\
\hline \multirow[t]{2}{*}{ Male } & 802 & - & Amphisbaena sp. (und.) & & - & - & - & - & - \\
\hline & & & Aniliidae & 6.25 & & & & & \\
\hline \multirow[t]{2}{*}{ Male } & 445 & 19.21 & Anilius scytale & & 11.0 & 315 & 9.17 & 0.48 & 0.71 \\
\hline & & & Colubridae & 6.25 & & & & & \\
\hline \multirow[t]{2}{*}{ Female } & 370 & - & Tantilla melanocephala & & 3.0 & 253 & - & - & 0.68 \\
\hline & & & Total & 100 & & & & & \\
\hline
\end{tabular}


tionately larger prey was detected, although this relationship was also not significant ( $\mathrm{rs}=-0.53, \mathrm{t}=-2.11, \mathrm{p}=0.057$ ) (Fig. 4). We observed a preference of $A$. scytale to feed on elongated vertebrates with a diameter less (36-84\%) than the diameter of their body (Tab. I).

\section{DISCUSSION}

The frequency of specimens with food items found in studies of snake diets is usually low, varying between $14 \%$ and $30 \%$ (Rodriguez-Robles \& Greene 1999, Shewchuk \& Austin 2001, Clark 2002, Ruffato et al. 2003, Gregory \& Izaac 2004, Hartmann et al. 2005, Balestrin et al. 2007, Leite et al. 2007, Prudente et al. 2007). This result may be related to the time of the year in which the analyzed specimens were collected, as suggested by GREGORY \& IsAAC (2004). READING \& DAviEs (1996) observed extended periods of "fasting" in gravid females of Natrix natrix Linnaeus, 1758, with the resumption of feeding after the reproductive period, and SHINE (1987) suggests that female snakes in general tend to reduce the consumption of food during the gestation period. Females with some type of food item were recorded only in the months between June and October, a period with low frequency of embryos. The low frequency of food items observed in $A$. scytale, mainly in the months of November to April, the period in which there are records of gravid females (see figure 5 in MASCHIO et al. 2007) may be a strong indication that females tend to reduce the consumption of food during the gestation period. Thus, future studies involving the analysis of a larger number of specimens collected throughout all the seasons of the year are necessary to reach more conclusive results.

Species of Leposternon Wagler, 1824, Aulura Barbour, 1914 and Amphisbaena, the most frequent items in the $\operatorname{diet}$ of $A$. scytale, are highly specialized for a fossorial life (Zug 1993, KEARNEY \& STUART 2004) and forage on the soil surface during the night, according to KeARney (2003). This fact, added to the records of Caecilia cf. gracilis, Atractus torquatus Duméril, Bibron and Duméril, 1854 (see Martins \& Oliveira 1998) and Tantilla melanocephala as food items of $A$. scytale, suggest that the species forages mainly on the ground. In addition to these observations, records of A. scytale in water bodies (Martins \& Oliveira 1998, G.F. Maschio pers. obs.) and the presence of $S$. marmoratus as a food item of A. scytale (Martins \& Oliveira 1998) are also evidence of the use of the aquatic environment as a foraging site.

The assumption that $A$. scytale forages on the ground can be reinforced by observations made by MArques \& SAZIMA (2008), which showed a behavior similar to constriction: if $A$. scytale does indeed subdue its prey by using a type of constriction behavior, this would only be possible on the soil surface, given that it is not feasible in underground galleries. But the possibility of $A$. scytale foraging and subduing its prey in galleries cannot be discarded, and more observations are needed to safely conclude whether $A$. scytale really subdues its prey on the ground, as suggested by the present study.
Regardless of the substrate used by A. scytale, the records of cannibalism observed by MAschio et al. (2005), the predominant presence of Amphisbaenidae in the stomach contents, recorded in this study, as well as the records of intake of other elongated vertebrates such as Caecilia cf. gracilis and $T$. melanocephala (this study), S. marmoratus and A. torquatus (see Martins \& Oliveira 1998) suggest that A. scytale does not discriminate between snakes and other small elongated vertebrates.

The direction of prey ingestion probably depends on the morphological characteristics of both the prey and the predator, as well as the behavioral characteristics that they exhibit during the different stages of their interactions (GREGory \& IZAAC 2004). The antero-posterior direction observed in all A. scytale is a pattern commonly observed in several species of snakes (Diefenbach \& Emslie 1971, Ashton 2002). This pattern is related mainly to the type of prey ingested, that usually shows rigid, pointed or sharp structures that could cause physical damage to the predator. Several species of Amphisbaena are able to inflict powerful bites, different to species of Leposternon that have an anti-predatory repertoire limited to flight and cloacal discharge (Marques \& SAZIma 1997). The fact that some Amphisbaenidae produce strong bites is enough to ensure that they are ingested headfirst, thereby decreasing the potential harm they could cause (see GrEENE 1976), and thus justifying the constriction behavior of A. scytale, as observed by Marques \& Sazima (2008).

According to SHINe (1987), the energetic cost of capturing and ingesting small prey is less than the energetic cost of predation of large prey, and the risks of injury are also lower with small prey. However, the theory predicts that foraging predators with access to prey of varying sizes will select larger prey, thus maximizing the foraging efficiency (SCHOENER 1972). On the other hand, the optimization of energy in an environment with low prey availability could also explain both the ingestion of prey with relatively large total lengths by adults and the inclusion of relatively small prey in the diet of large snakes (SHINe 1991). The indiscriminate capture of both proportionately large and small prey by A. scytale may reflect its opportunistic behavior. However, the tendency for juveniles of $A$. scytale to eat proportionately larger prey (Fig. 3) may be associated with both the low availability of prey of a size compatible to that of the juveniles, as well as the inexperience of the juveniles in selecting their prey (see SAZIMA \& MARTINs 1990).

Basal Alethinophidia, which include the Neotropical Anilius and the Asiatic Cylindrophis, present a series of cranial modifications that are related to their adaption as burrowing snakes: skull of compact structure with leveled surface, and the snout characterized by a firm maxillary arch formed by the premaxilla, the maxilla and the ectopterigoid that is solidly united to the palate (RiEppel 1977), among others. These characteristics limits the cranial kinesis of the basal Alethinophidia compared with Macrostomata, and the ability to consume prey with larger diameter or similar to the diameter of their body, which in theory would limit the selection of prey. Therefore, 
these cranial modifications could explain the preference of $A$. scytale for feeding on elongated vertebrates with a diameter less than the diameter of their body.

Since both the density and availability of prey may influence the selection of prey with particular sizes (Plummer \& Goy 1984, SHINE 1987, 1991), the reason why A. scytale includes both large and small prey in its diet is still inconclusive, due to lack of information on the actual abundance of different species recorded as food items of $A$. scytale.

\section{ACKNOWLEDGMENTS}

We thank Mark Wilkinson, The Natural History Museum, London, UK, for the identification of the Caecilia cf. gracilis, and three anonymous reviewers for valuable comments on the manuscript. ALCP thanks Conselho Nacional de Desenvolvimento Científico e Tecnológico (CNPq, Edital Universal, Proc. 476096/ 2006-5; PQ Proc. 307999/2008-4) for financial support. GFM and FRS thank the CNPq for financial support.

\section{LITERATURE CITED}

Ashton, K.G. 2002. Headfirst ingestion of prey by rattlesnakes: are tactile cues used? Journal of Herpetology 36 (3): 500-502.

Balestrin, R.L.; M. Di-Bernardo \& A.G. Moreno. 2007. Feeding ecology of the Neotropical Worm Snake, Atractus reticulatus (Boulenger, 1885) (Serpentes - Colubridae), in southern Brazil. Herpetological Journal 17: 62-64.

BeевE, W. 1946. Field notes on the snakes of Kartabo, British Guiana, and Caripito, Venezuela. Zoologica 4: 11-52.

Bertona, M. \& M. Chiaraviglio. 2003. Reproductive biology, mating aggregations, and sexual dimorphism of the Argentine Boa Constrictor (Boa constrictor occidentalis). Journal of Herpetology 37: 510-516.

Clark, R.W. 2002. Diet of the Timber Rattlesnake, Crotalus horridus. Journal of Herpetology 36 (3): 494-499.

Cunha, O.R. \& F.P. Nascimento. 1978. Ofídios da Amazônia X As cobras da região leste do Pará. Boletim do Museu Paraense Emílio Goeldi 31: 1-218.

CunHA, O.R. \& F.P. NAscimento. 1981. Ofídios da Amazônia XII Observações sobre a viviparidade em ofídios do Pará e Maranhão (Ophidia: Aniliidae, Boidae, Colubridae e Viperidae). Boletim do Museu Paraense Emílio Goeldi 109: 1-20.

Cunha, O.R. \& F.P. Nascimento. 1993. Ofídios da Amazônia. As cobras da região leste do Pará. Boletim do Museu Paraense Emílio Goeldi 9: 1-191.

D’Agostino, R.B.; A. Belanger \& R.B. D’Agostino Jr. 1990. A suggestion for using powerful and informative tests of normality. The American Statistical 44 (4): 316-321.

Diefenbach, C.O. \& S.G. Emslie. 1971. Cues influencing the direction of prey ingestion of the Japanese snake, Elaphe climacophora (Colubridae, Serpentes). Herpetologica 27: 461-466.

Dixon, J.R. \& P. Sorni. 1977. The reptiles of the upper Amazon basin, Iquitos region, Peru. II. Crocodilians, turtles and snakes.
Contributions in Biology and Geology Milwaukee Public Museum 12: 1-71.

Dixon, J.R. \& P. SoInI. 1986. The Reptiles of the Upper Amazon Basin, Iquitos Region, Peru. Milwaukee, Milwaukee Public Museum, 154p.

Duellman, W.E. 1978. The biology of an equatorial herpetofauna in Amazonian Ecuador. University of Kansas Natural History Museum 65: 1-352.

Greene, H.W. 1976. Scale overlap, a directional sign stimulus for prey ingestion by ophiophagous snakes. Zeitschrift für Tierpsychologie 41: 113-120.

GreENe, H.W. 1983. Dietary correlates of the origin and radiation of snakes. American Zoology 23: 431-441.

Gregory, P.T. \& L.A. IsaAc. 2004. Food habits of the Grass Snake in southeastern England: is Natrix natrix a generalist predator? Journal of Herpetology 38 (1): 88-95.

Hartmann, M.T.; P.A. Hartmann; S. Cechin \& M. Martins. 2005. Feeding habits and habitat use in Bothrops pubescens (Viperidae, Crotalinae) from Southern Brazil. Journal of Herpetology 39 (4): 664-667.

Harlow, P.S. \& R. Shine. 1992. Food habits and reproductive biology of the Pacific island boas (Candoia). Journal of Herpetology 26: 60-66.

Kearney, M. 2003. Diet in the Amphisbaenian Bipes biporus. Journal of Herpetology 37: 404-408.

Kearney, M. \& B.L. Stuart. 2004. Repeated evolution of limblessness and digging heads in worm lizards revealed by DNA from old bones. Proceedings of the Royal Society 271: 1677-1683.

LeITE, O.T.; S.F. Nunes \& S.Z.Cechin. 2007. Dieta e uso de habitat da jararaca-do-brejo, Mastigodryas bifossatus Raddi (Serpentes, Colubridae) em domínio subtropical do Brasil. Revista Brasileira de Zoologia 24 (3): 729-734.

Lourdais, O.; R. Shine; X. Bonnet \& F. Brischoux. 2006. Sex differences in body composition, performance and behaviour in the Colombian rainbow boa (Epicrates cenchria maurus, Boidae). Journal of Zoology 269: 175-182.

Marques. O.A.V. \& I. Sazima. 1997. Diet and feeding behavior of the snake, Micrurus corallinus, from the Atlantic Forest of Brazil. Herpetological Natural History 5 (1): 88-93.

Marques, O.A.V. \& I. Sazima. 2008. Winding to and fro: constriction in the snake Anilius scytale. 2008. Herpetological Bulletin 103: 29-31.

Martins, M. \& M.E. Oliveira. 1998. Natural history of snakes in forests of the Manaus region, Central Amazonia, Brazil. Herpetological Natural History 6 (2): 78-150.

Maschio, G.F.; A.C. Lima \& A.L.C. Prudente. 2005. Anilius scytale (Red Pipesnakes). Cannibalism. Herpetological Review 36(2): 187-187.

Maschio, G.F.; A.L.C. Prudente; A.C. Lima \& D.T. Feitosa. 2007. Reproductive biology of Anilius scytale (Linnaeus, 1758) (Serpentes, Aniliidae) from eastern Amazonia, Brazil. South American Journal of Herpetology 2 (3): 179-183. 
Plummer, M.V. \& J.M. Goy. 1984. Ontogenetic dietary shift of water snakes (Nerodia rhombifera) in a fish hatchery. Copeia 1984: 550-552.

Prudente, A.L.C; G.F. Maschio; C.E. Yamashina \& M.C. SantosCosta. 2007. Morphology, reproductive biology and diet of Dendrophidion dendrophis (Schlegel, 1837) (Serpentes, Colubridae) in Brazilian Amazon. South American Journal of Herpetology 2 (1): 53-58.

ReAding, C.J. \& J.L. Davies. 1996. Predation by Grass Snakes (Natrix natrix) at a site in southern England Journal of Zoology 239: 73-82.

RIEPpeL, O. 1977. Studies on the skull of the Henophidia (Reptilia: Serpentes). Journal of Zoology 181: 145-173.

Rodriges-Robles, J.A. 2002. Feeding ecology of North American gopher snakes (Pituophis catenifer, Colubridae). Biological Journal of the Linnean Society 77: 165-183.

Rodriges-Robles, J.A. \& H.W. Greene. 1999. Food habits of the long-nosed snake (Rhinocheilus lecontei), a "specialist" predator? Journal of Zoology 248: 489-499.

Ruffato, R; M. Di-Bernardo \& G.F. Maschio. 2003. Dieta de Thamnodynastes strigatus (Serpentes, Colubridae) no sul do Brasil. Phyllomedusa 2 (1): 27-34.

Shewchuk, C.H. \& J.D. Austin. 2001. Food habits of the racer (Coluber Constrictor mormon) in the northern part of its range. Herpetological Journal 11: 151-155.
Sazima, I. \& M. Martins. 1990. Presas grandes e serpentes jovens: quando os olhos são maiores que a boca. Memórias do Instituto Butantan 52: 73-79.

Schoener, T.W. 1972. Theory of feeding strategies. Annual Review of Ecology, Evolution and Systematics 2: 269-404.

SHINE, R. 1987. Ecological ramifications of prey size: Food habits and reproductive biology of australian copper head snakes (Austrelaps, Elapidae). Journal of Herpetology 21 (1): 21-28.

SHINE, R. 1991. Why do larger snakes eat larger prey? Functional Ecology 5: 493-502.

SiLva-JR, N.J. 2001. Anilius scytale (Blind Coral Snake). Herpetological Review 32(4): 277-277.

SuIP, D.J. \& R. SHINe. 1988. Feeding Habits of the Diamond Python, Morelia s. spilota: Ambush Predation by a Boid Snake. Journal of Herpetology 22 (3): 323-330.

StATSOFt, Inc. 2001. STATISTICA (data analysis software system), version 6.Statsoft Inc.

VANZOLINI, P.E. 1986. Levantamento herpetológico da área do Estado de Rondônia sob a influência da rodovia BR 364. Brasília, CNPq, Programa Polonoroeste, Subprograma Ecologia Animal, Relatório de Pesquisa \#1, CNPq, Brasília, 50p.

ZAR, J. H. 1996. Biostatistical Analysis. New Jersey, PrenticeHall, 662p.

ZUG, G.R. 1993. Herpetology: an introductory biology of amphibians and reptiles. San Diego, Academic Press, 527p.

Appendix 1. Specimens of Anilius scytale analized (Herpetological Collection of the Museu Paraense Emílio Goeldi - MPEG).

Brazil, Amazonas, Manaus: MPEG 16402 (June, 1980). Maraã: MPEG 16782 (November/1983). Caracará: MPEG 17299 (March/1986). Presidente Figueiredo: MPEG 17382, 17428, 17433, 17456 (November/1987), 17505, 17518, 17547 (April/1988). Tefé: MPEG 18228 (November/1989). Maranhão, Arari: MPEG 14453, 15300 (February/1979), 15419 (July/1976). Nova Vida: MPEG 12675 (October/1976), 11091, 16039 (February/1975). Paruá: MPEG 12024, 12025, 12026, 12028, 12832 (July/1976). Pará, Ananindeua: MPEG 18904 (January/1991). Apeú: MPEG 843 (September/1971), 1477 (February/1972). Augusto Corrêa: MPEG 806 (September/ 1971), 1375 (April/1972), 1801 (june/1972), 2357, 2358, 3221 (August/1972), 4583 (July/1973), 5331, 5336, 5338, 5339, 5350, 5362, 5363 (October/1073), 6493, 6653, 6664, 6690 (March/1974), 8993, 8995, 9086, 9087 (March/1975), 10002 (June/1975), 10721, 10722, 10723, 10724 (October/1975), 12452, 12453 (June/1976). Belém: MPEG 259, 764 (August/1971), 771 April/ 1971), 1849 (July/1972), 16561 (September/1983), 17630 (March/1988), 18600 (November/1988), 18635 (November/2006), 18689 (January/1993), 18781 (April/1994), 18898 (June/1989), 19304 (July/206), 19757 (June/2000), 19826 (March/2001), 19848 (January/1994). Benevides: MPEG 747, 748, 828, 834 (September/2006), 5475 (February/1976), 5476 (September/1971). Bragança: MPEG 2249 (August/1972), 4397, 7891 (August/2006), 5081, 5088, 8237, 8259, 8250, 8265, 8281, 12993, 12995, 12996, 12997 (October/2006), 6319 (March/2006), 11304, 11307 (November/2006). Canaã dos Carajás: MPEG 20627 (April/2008). Capitão Poço: MPEG 2132 (September/1979), 4925 (October/1973), 6057, 6088, 6090 (March/2006), 7243 (March/1974), 9678, 9679 (March/1975), 9680 (June/1975), 10655 (October/1975), 12191, 12192 (June/1976), 12981 (October/2006), 13042, 14050, 14058 (October/1997), 15402 (November/1975). Castanhal: MPEG 12602 (September/1976). Conceição do Araguaia: MPEG 16950 (May/1985). Curuçá: MPEG 4062, 4873, 4892 (July/1973), 7110 (July/1974), 7588, 7589, 7592, 7599, 7603 (October/ 1974). Gurupá: MPEG 15443 (April/2006). Igarapé-açú: MPEG 858, 859, 860, 861, 876, 877, 878, 892 (September1971). Marabá: MPEG 7452 (July/1974), 16965, 17083 (May/1985). Maracanã: MPEG 5802 (March/1974). Mosqueiro: MPEG 16823 (July/1981). Ourém: MPEG 1662 (June/1972), 4247 (August/1973), 6193 (March/1974), 7006 (August/1974). Paragominas: MPEG 18846 (July/1994). Porto Jarbas Passarinho: MPEG 12949 (June/1976). Santa Rosa: MPEG 4011 (July1973), 4666, 4691 (October/1973), 5673 (March/1974), 6906 (June/1974), 7484, 7486, 7511, 7531 (September/1974), 8484, 8489 (February/1975), 11833 (May/ 1976), 12591 (September/1976). Santarém: MPEG 19101 (April/1995). Viseu: MPEG 1073 (November/1971), 7667 (July/1974), 12326 (June/1976), 15982, 15983 (August/1979), 16004 (August/2006). 
Appendix 2. Prey of A. scytale analized (Herpetological Collection of the Museu Paraense Emílio Goeldi - MPEG).

Caecilia cf. gracilis (MPEG 17382); Amphisbaena amazonica (MPEG 843, 16965); Amphisbaena mitchelli (MPEG 7667); Amphisbaena sp. (MPEG 2249, 4666, 8259, 15982); Aulura anomala (MPEG 876, 7452, 9680); Leposternom polystegum (MPEG 5336, 9993, 12026); Anilius scytale (MPEG 7243); Tantilla melanocephala (MPEG 12326).

Submitted: 01.VI.2009; Accepted: 23.1.2010.

Editorial responsibility: Walter P. Boeger

ZOOLOGIA 27 (2): 184-190, April, 2010 